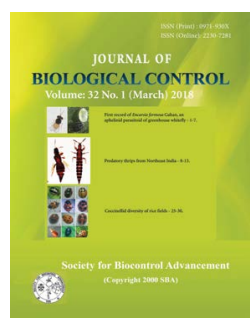

\title{
Thrips and their natural enemies in different ornamental plants of Himachal Pradesh
}

\author{
SUMAN SANJTA ${ }^{\mathbf{*}}$, USHA CHAUHAN ${ }^{\mathbf{1}}$ and PAWAN KUMAR MEHTA ${ }^{2}$ \\ ${ }^{1}$ Department of Entomology, Dr. Y S Parmar University of Horticulture and Forestry, Nauni, Solan - 173230, Himachal \\ Pradesh, India \\ ${ }^{2}$ Department of Entomology, CSKHPKV Palampur, Kangra - 176062, Himachal Pradesh, India \\ ${ }^{*}$ Corresponding author E-mail: sumansanjta@gmail.com
}

\begin{abstract}
During a survey conducted in different ornamentals under mid-hill conditions of Himachal Pradesh, twenty six species of thrips viz. Thrips spp. (two different species), T. tabaci Lindeman, T. flavus Schrank, T. flavidulus Bagnall, T. carthami Shumsher Singh, T. palmi Karny, T. kodaikanalensis Ananthakrishnan and Jagadish, T. simplex Morison, T. hawaiiensis Morgan, T. setosus Moulton, T. andrewsi Bagnall, T. florum Schmutz, T. himalyanus Pelikan, Taeniothrips sp., Microcephalothrips abdominalis Crawford DL, Frankliniella sulphurea Trybom, Neohydatothrips samayankur Kudo, Megalurothrips sp., Scirtothrips dorsalis Hood, Scolothrips sexmaculatus Pergande, Aeolothrips spp. and A. indicus Bhatti, Haplothrips? tenuipennis, Haplothrips tenuipennis Bagnall and H.clarisetis Priesner were reported. Out of these, Thrips tabaci and Thrips flavus dominated all species by contributing 10 and 18.33 per cent, respectively. Among natural enemies Orius sp., Coccinella septempunctata, Hipodamia variegata, Oenopia Kirby, Amblysieus sp, Euseius sp and spiders (unidentified) were found. The results of this study update the list of thrips and their associated natural enemies in the state. It paves new ways for the researchers for future studies on the thrips and their impact as the vectors of diseases and assessment of predatory potential of different predatory species of thrips and natural enemies can be exploited for the management of pest species.
\end{abstract}

KEY WORDS: Himachal Pradesh, natural enemies, ornamental, thrips

(Article chronicle: Received: 09-08-2017; Revised: 08-02-2018; Accepted: 12-03-2018)

\section{INTRODUCTION}

Mid hills of Himachal Pradesh are located between $30^{\circ} 85^{\prime} \mathrm{N}-32^{\circ} 29^{\prime} \mathrm{N}$ latitude and $75^{\circ} 10^{\prime} \mathrm{E}-77^{\circ} 16^{\prime} \mathrm{E}$ longitude at an altitude of 935-1525 meters above mean sea level. Due to its unique geographical position and edapho-climatic conditions, it is suitable for growing different kinds of ornamental plants (Thakur et al., 2009). Ornamental plants are grown for their aesthetic value and for commercial purpose as cut flower, loose flowers and seed purpose. Many different kinds of insects and mites i.e., tetranychid mites, aphids, thrips etc. feed on ornamental plants which hamper their aesthetic and economic value (Mirab-balou et al., 2009), out of which thrips are reported to be one of the important pest. Because of the small size of thrips, life stages and rapid movement make it difficult to detect these insects in fresh vegetation, and they also can transmit viruses on different plants
(Silagyi and Dixon, 2006; Parrella et al., 2003). During the past decades, the losses of agricultural and horticultural produce caused by thrips increased considerably, resulting in losses of millions of dollars (ThripsWiki, 2015). Despite postharvest and quarantine procedures, thrips species are spreading worldwide very quickly. Insecticide resistance has continued to be a widespread problem with the thrips, as populations have continued to evolve resistance to all manner of new insecticides (Gao et al., 2012). Therefore, to combat insecticide resistance in the thrips noninsecticidal tactics, such as biological control is required. Various species have been reported to feed on thrips. The most abundant group of natural enemies of thrips are eulophids, anthocorid bugs, predatory mites, coccinellids, neuropterans, cecidomyiid and spiders (Yee et al., 2000). But from Himachal Pradesh, no earlier reports are present on this aspect. In view of this, the present investigation was carried out to study the diversity of the thrips fauna and its 
associated natural enemies in different vegetable crops in the mid hill conditions of Himachal Pradesh.

\section{MATERIALS AND METHODS}

The study was carried out at Nauni, (1275 meters above mean sea level) and surrounding areas (near University campus of UHF, Nauni) in Solan district of Himachal Pradesh. Thrips and their natural enemies were collected from different ornamentals (Table 1) in both seasons (summer and winter) of the year during 2013 and 2014. At each collection site, five plants were randomly selected for sampling. From each plant five leaves or flowers were selected randomly for collection and were beaten on white tray with a stick. The fallen thrips were collected in the collecting fluid containing 60\% alcohol and glacial acetic acid (9:1) with Triton-X $(1 \mathrm{~mL} / 1000 \mathrm{~mL})$ and were mounted as prescribed by Bhatti (1999). The natural enemies were collected and preserved by carding or pinning. The slides with mounted specimens were observed under phase contrast microscope. Thrips were identified using taxonomic keys, digital images and descriptions of Palmer (1992), Bhatti (1980), Ananthakrishnan and Sen (1980), and Masumoto (2010). Some of the specimens were sent to Dr J S Bhatti (Retired Prof, Hans Raj college, Delhi), Dr. Vikas Kumar (Scientist C, CDT, ZSI, Kolkata) and Dr. Koumud Tyagi (PDF, CDT, ZSI, Kolkata) for identification or confirmation of identity. Natural enemies were identified with the identified reference specimens present in the laboratory. For estimating the diversity of thrips and their associated natural enemies the data of individual plants/trees of fruits, vegetables, ornamentals and medicinal plants was pooled together. The species which were present in negligible numbers were not considered for diversity calculations. The following formulae were used:

Relative proportion of ith species $=$

\section{Total number of individuals of ith species}

Total number of individuals of all the species

Diversity indices: Diversity indices like Shannon diversity index, maximum diversity, species evenness and species dominance was calculated as per procedure given by Shannon (1948) which is described as under:

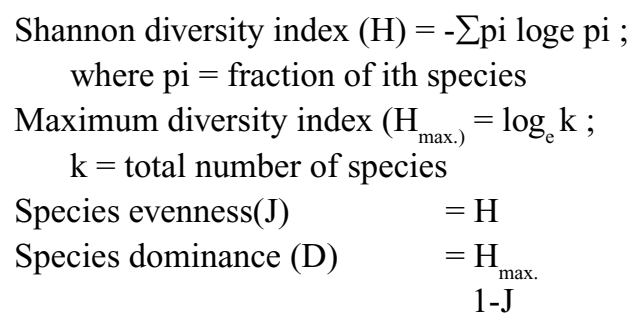

\section{RESULTS AND DISCUSSION}

During the investigation, twenty six species of thrips were recorded in different ornamentals like rose, chrysanthemum, calendula, helichrysum, hydrangea, bouganvillea, marigold, geranium, acania, pansy, nastruitium, lupin, sweet allysum, sweet william, gladiolus, dahlia, daisy, carnation, wall flower and weeping willow. Among the identified thrips, twenty two species were phytophagous and four were predatory. The phytophagous species were Thrips spp. (two different species), T. tabaci, T. simplex, T. carthami, T. palmi, T. andrewsi T. himalyanus T. setosus T. hawaiiensis, T. kodaikanalensis, T. florum, T. flavus, T. flavidulus, Scirtothrips dorsalis, Megalurothrips peculiaris, Neohydatothrips samayankur, Frankliniella sulphurea, Taeniothrips sp. Microcephalothrips abdominalis Haplothrips clarisetis, Haplothrips tenuipennis and Haplothrips ?tenuipennis. Predatory species were Scolothrips sexmaculatus, Aeolothrips sp. and A. indicus. Sood and Kakkar (1990) conducted a survey on ornamentals in different areas of Himachal Pradesh. The ornamentals surveyed were iris, rose, dahlia, sweet pea, chrysanthemum, marigold, zinnia, calendula, carnation, nastruitium, oriental poppy, phlox, hibiscus, sweet william, celosia and gladiolus. They reported eleven species of thrips which were Frankliniella schultzei, Microcephalothrips abdominalis, Lefroyothrips lefroyi, Megalurothrips distalis, Thrips flavus, T. hawaiiensis, Taeniothrips flavus, Haplothrips ganglbaueri, Haplothrips coloratus and Liothrips sp. However, they didn't record any predatory thrips species whereas in the present study three predatory species were recorded. Lefroyothrips lefroyi, Megalurothrips distalis, Haplothrips ganglbaueri Haplothrips coloratus and Liothrips sp., which were reported by Sood and Kakkar (1990), couldn't be collected in the present study. The difference could be due to different crops and locality surveyed. Sood and Kakkar (1990) conducted survey in different areas of Himachal Pradesh whereas present survey was confined to Nauni and surrounding areas. Among natural enemies Orius sp., Coccinella septempunctata, Hippodamia variegata, Oenopia Kirby, Amblysieus sp. Euseius sp. and spiders (unidentified) were found.

Table 1. Different ornamental crops surveyed

\begin{tabular}{|l|l|}
\hline $\begin{array}{l}\text { Ornamental } \\
\text { plants }\end{array}$ & $\begin{array}{l}\text { Rose (Rosa } \text { sp.), gladiolus (Gladiolus hybrid), } \\
\text { marigold (Tagetus spp.), carnation (Dianthus } \\
\text { caryophylllus), chrysanthemum (Dendranthema } \\
\text { grandiflorum), jasmine (Jasminum sp.), hydran- } \\
\text { gea (Hydrangea macrophylla), annuals (winter } \\
\text { and summer), weeping willow, bottle brush, } \\
\text { bouganvillea }\end{array}$ \\
\hline
\end{tabular}

Among natural enemies Orius sp. occurred in rose, chrysanthemum and dahlia and spiders were present on bougainvillea, helichrysum and rose. Coccinella septempunctata was found on rose, helichrysum and nastruitium, whereas, Oenopia kirbyi was collected from helichrysum and calendula. Hippodamia variegata, Amblysieus sp. and Euseius 
SUMAN SANJTA et al.

Table 2. Distribution of Thrips and their natural enemies in different ornamental plants

\begin{tabular}{|c|c|c|c|c|}
\hline Order & Family & Species & Crop & Location \\
\hline \multirow[t]{27}{*}{ Thysanoptera } & \multirow[t]{22}{*}{ Thripidae } & Thrips tabaci & $\begin{array}{l}\text { Chrysanthemum, calendula, helichry- } \\
\text { sum, hydrangea, bouganvillea }\end{array}$ & Nauni, Gaura \\
\hline & & Thrips sp. & Sweet william, candy tuft & Nauni \\
\hline & & Thrips sp. & Bells of Ireland & Nauni \\
\hline & & Thrips flavus & Marigold, calendula, geranium & Nauni, Gaura \\
\hline & & Thrips palmi & $\begin{array}{l}\text { Marigold, nastruitium, calendula, } \\
\text { pansy, lupin, sweet allysum }\end{array}$ & \\
\hline & & Thrips flavidulus & Marigold, acania, pansy, & Nauni \\
\hline & & Thrips carthami & Marigold, nastruitium, calendula, pansy & Nauni \\
\hline & & Thrips setosus & Lupin, calendula, sweet William & Nauni \\
\hline & & Thrips kodaikanalensis & Helichrysum & Nauni \\
\hline & & Thrips simplex & Gladiolus & Nauni \\
\hline & & Thrips hawaiiensis & Rose, acania, marigold, dahlia & Nauni, Gaura \\
\hline & & Thrips andrewsi & Rose, lupin & Nauni \\
\hline & & Thrips florum & Rose, dahlia & Nauni, Gaura \\
\hline & & Thrips himalyanus & African daisy, marigold, sweet allysum & Nauni \\
\hline & & Taeniothrips sp. & Lupin, bouganvillea & Nauni \\
\hline & & Retithrips syriacus & Acania & Nauni \\
\hline & & $\begin{array}{l}\text { Microcephalothrips ab- } \\
\text { dominalis }\end{array}$ & Marigold, lupin, rose & Nauni \\
\hline & & Frankliniella sulphurea & Carnation & Nauni \\
\hline & & $\begin{array}{l}\text { Neohydatothrips sama- } \\
\text { yankur }\end{array}$ & Marigold & $\begin{array}{l}\text { Nauni, Rajgarh, } \\
\text { Gaura }\end{array}$ \\
\hline & & Megalurothrips peculiaris & Calendula & Nauni \\
\hline & & Scirtothrips dorsalis & Weeping willow & Nauni \\
\hline & & Scolothrips sexmaculatus & Rose & Nauni \\
\hline & \multirow[t]{2}{*}{ Aeolothripidae } & Aeolothrips sp. & Wall flower & Nauni \\
\hline & & Aeolothrips indicus & Calendula, lupin & Nauni \\
\hline & \multirow[t]{3}{*}{ Phlaeothripidae } & Haplothrips tenuipennis & $\begin{array}{l}\text { Helichrysum, chrysanthemum, dahlia, } \\
\text { pansy, rose, sweet william }\end{array}$ & Nauni, Gaura \\
\hline & & Haplothrips ?tenuipennis & Candy tuft & Nauni \\
\hline & & Haplothrips clarisetis & Chrysanthemum, helichrysum & Nauni \\
\hline Hemiptera & Anthocoridae & Orius sp. & Rose, Chrysanthemum, dahlia & Nauni \\
\hline \multirow[t]{3}{*}{ Coleoptera } & \multirow[t]{3}{*}{ Coccinellidae } & Coccinella septempunctata & Rose, Helichrysum, Nastruitium & Nauni, Gaura \\
\hline & & Hippodamia variegata & Rose & Nauni \\
\hline & & Oenopia kirbyi & Rose & Nauni \\
\hline \multirow[t]{2}{*}{ Mesostigmata } & \multirow[t]{2}{*}{ Phytoseiidae } & Amblyseius sp. & Rose & Nauni \\
\hline & & Euseius sp. & Rose & Nauni \\
\hline
\end{tabular}

Table 3. Diversity of thrips and natural enemies on ornamental plants

\begin{tabular}{|l|c|}
\hline Species & \multirow{2}{*}{ Relative proportion (\%) } \\
\cline { 1 - 2 } A. Phytophagous species & 10 \\
\hline Thrips tabaci & 18.33 \\
\hline Thrips flavus & 3.33 \\
\hline Thrips flavidulus & 3.33 \\
\hline Thrips carthami & 1.67 \\
\hline Thrips setosus & 3.33 \\
\hline Thrips palmi & 1.67 \\
\hline Thrips kodaikanalensis & 1.67 \\
\hline Thrips simplex & 3.33 \\
\hline Thrips hawaiiensis & 1.67 \\
\hline Thrips andrewsi & 5 \\
\hline Thrips florum & 3.33 \\
\hline Thrips himalyanus & 1.67 \\
\hline Frankliniella sulphurea & 1.67 \\
\hline Taeniothrips sp. & \\
\hline
\end{tabular}


Thrips and their natural enemies in different ornamental plants of Himachal Pradesh

\begin{tabular}{|l|l|}
\hline Microcephalothrips abdominalis & 6.67 \\
\hline Neohydatothrips samayankur & 3.33 \\
\hline Megalurothrips peculiaris & 1.67 \\
\hline Scirtothrips dorsalis & 1.67 \\
\hline Haplothrips clarisetis & 1.67 \\
\hline Haplothrips tenuipennis & 3.33 \\
\hline Haplothrips ? tenuipennis & 1.67 \\
\hline B. Predatory species & 1.67 \\
\hline Scolothrips sexmaculatus & \\
\hline Aeolothrips sp. & 1.67 \\
\hline Aeolothrips indicus & 1.67 \\
\hline Amblyseius sp. & 1.67 \\
\hline Euseius sp. & 1.67 \\
\hline Orius sp. & 5 \\
\hline Hippodamia variegata & 1.67 \\
\hline Coccinella septempunctata & 3.33 \\
\hline Oenopia kirbyi & 1.67 \\
\hline Spiders (unidentified) & 1.67 \\
\hline Total & 100 \\
\hline Shanon index (H) & 3.27 \\
\hline H & 3.4 \\
\hline Evenness (J) & 0.96 \\
\hline Dominance (D) & 0.04 \\
\hline & \\
\hline
\end{tabular}

sp. were collected from only rose. Nisha Devi and Gupta (2010) recorded two species of predacious anthocorid bugs, namely Orius niger Wolff and $O$. bifilarus Ghauri feeding on thrips collected from jasmine from Solan. Sanjta and Chauhan (2015) also recorded Orius sp., Oenopia kirbyi and Coccinella septempunctata feeding on thrips from Nauni, Soaln on different fruit trees. Greenberg et al., (2009) also recorded Orius spp., Hippodamia spp.(Coccinellid beetles) and spiders associated with thrips on cotton in Texas. Amblysieus sp. and Euseius sp. were also recorded by Chandel and Chauhan (2014) from Solan on rose.

\section{ACKNOWLEDGEMENT}

Authors are grateful to Dr J S Bhatti (Retd. Prof. Hans raj College), Dr Laurence Mound (CAB International Institute of Entomology), Dr. Vikas Kumar (Scientist C, CDT, ZSI, Kolkata) and Dr Kaumud Tyagi (PDF, CDT, ZSI, Kolkata) for identification of certain specimens, for providing literature and valuable suggestions.

\section{REFERENCES}

Ananthakrishnan TN, Sen S. 1980. Taxonomy of Indian Thysanoptera. ZSI Handbook Series 1: 1-234.

Bhatti JS. 1980. Species of the genus Thrips from India (Thysanoptera). Syst Entomol. 5: 109-166. https://doi. org/10.1111/j.1365-3113.1980.tb00404.x
Bhatti JS. 1999. Enigmatic tentorium in adults of the Onion thrips, Thrips tabaci. Thrips 1: 15-30.

Chandel V, Chauhan U. 2014. Diversity of mite (Acari) fauna associated with vegetables and ornamental plants in midhill conditions of Himachal Pradesh. $J$ Biol Control. 28(2): 18-2

Gao, Y, Lei, Z, Reitz, SR. 2012. Western flower thrips resistance to insecticides: detection, mechanisms and management strategies. Pest Manag Sci. 68: 11111121. https://doi.org/10.1002/ps.3305 PMid:22566175

Masumoto M. 2010. Key to genera of the subfamily Thripinae (Thysanoptera: Thripidae) associated with Japanese plant quarantine. Res Bull Pl Prot Station Japan 46: 25-59.

Majid M. 2014. Newly recorded species of the genus Haplothrips (Insecta: Thysanoptera) from Iran. J Crop Prot. 3(4): 557-561.

Devi N, Gupta PR. 2010. Anthocorid bugs encountered on cultivated crops and ornamentals, and an attempt to rear Orius niger Wolff under laboratory conditions. Pest Manag Econ Zool. 18(1): 313-320.

Palmer JM. 1992. Thrips from Pakistan to the Pacific: a review. Bull Br Mus Nat Hist Entomol. 61: 1-76. 
SUMAN SANJTA et al.

Parrella G, Gognalons P, Gebreselassie K, Vovlas C, Marchoux G. 2003. Update of the host range of tomato spotted wilt virus. J Plant Pathol. 85: 227-264.

Sanjta S, Chauhan U. 2015. Survey of thrips fauna and their natural enemies in different fruit crops under mid hills of Himachal Pradesh. J Insect Sci. 28(2):202-207.

Shannon CE. 1948. A mathematical theory of communication. Bell System Tech J. 27: 379-423. https://doi. org/10.1002/j.1538-7305.1948.tb00917.x

Silagyi AJ, Dixon WN. 2006. Assessment of chilli thrips, Scirtothrips dorsalis, in Florida. Florida Cooperative Agricultural Pest Survey, Division of Plant Industry, Florida Department of Agriculture and Consumer Services, Gainesville.
Sood AK, Kakar KL. 1990. Record of insect and non-insect pests on ornamental plants from Himachal Pradesh. $J$ Insect Sci. 3(2): 141-145.

Thakur P, Kashyap B, Gupta YC. 2009. Wild ornamental bulbous plants of Himachal Pradesh for landscaping. Int $J$ Forest Usufructs Mgmt. 10(1): 67-74.

Thrips wiki. 2015 Available from: http:// thrips.info/w/index. phptitle=Main_Page\&oldid=49404

Yee WL, Phillips PA, Rodgers J, Faber BA. 2000. Abundance and population trends of predators of Scirtothrips perseae and Oligonychus perseae on avocado in Ventura County, California. California conference on biological control II, The Historic Mission Inn Riverside, California USA. pp. 195-200. 